\title{
Democratization in Information Technology Era: Indexing and Categorizing
}

\author{
George Towar Ikbal Tawakkal \\ \{george.ikbal@ub.ac.id\} \\ Universitas Brawijaya, Indonesia
}

\begin{abstract}
The achievement of information technology has influenced various aspects of life, including democratic life. Many governments have developed electronic government (e-government) to create better governance, to increase democratization. Quickly, egovernment is believed to be the best way and then became a program in many countries. Some international and national institutions address this phenomenon by making an assessing or indexing of the achievements of e-government, such as the UN releasing The E-Government Index (EGI), e-Governance Academy Foundation releasing The National Cyber Security Index (NCSI), the Open Knowledge Foundation releasing The Global Open Data Index (GODI), and even some countries assess the implementation of egovernment at every level of government, such as for example Indonesia with the Indonesian E-Government Rating (PeGI). This paper discusses the focus and method of these indexes. By identifying and analyzing their reports and websites, this paper looks for differences and builds the categorization of these indexes. This paper categorizes indices into three categories: the managerial indices, the human resources indices, and the democratic indices.
\end{abstract}

Keywords: Information Technology; E-government; Democratization; Index.

\section{Introduction}

The achievement of technology and the use of the internet have presented opportunities to share data easily and cheaply, regardless of the distance between data providers and data users. These new opportunities provide opportunities for people to access new products and services that are always evolving. It's easy to prove that this innovation is changing the environment, where companies, governments, and communities are connected between them. This innovation brings changes about how they received the information, saved it and sent it. In this new order, dissemination, acceleration, adaptability, and creativity are crucial.

Utilization of the internet for commercial purposes began when in the 1990s many companies used internet technology to introduce their products and services [1]. Quickly, the private sector adopted it. The phenomenon that arises after the use of internet technology in the private sector is the use of technology in the public sector. Many governments build egovernment to facilitate the exchange of information between government and citizens. The use of internet technology in the public sector, at first was still simple, until later it developed and influenced governance. This important achievement causes e-government not only to manage governance but also to move democracy. Given the opportunities and benefits that can 
be generated, many governments focus on developing e-government in improving public services and democratization.

Many explanations regarding e-government. According to the Center for Democracy and Technology [2], e-government has been seen as the employ of information technology in the rearrangement of government through increased accessibility, effectiveness, and responsibility. The European Commission [3] underlines that the transformation can combine itself with organizational changes and new skills, thereby increasing public services, increasing democratic participation and strengthening the implementation of public policies. Even the International Center for Policy Studies [4] said that e-government has the power to change the scale and grade of relations between public offices and citizens. So, achieving the benefits of implementing e-government was not only decided by technological achievement but also on the growth of resources and strategies in government organizations.

An almost similar definition was conveyed in the 2003 United Nations Report [5], egovernment is a government that implements information technology to change external and internal interactions. Through applying information technology, public administration did not only involves transforming activities or task that remain formal, accountable, functional, and transparent but also impacted to growth of public expectations for higher-level government in all sectors. The clearest benefit of e-Government is that it gives national governments the opportunity to connect with citizens. As is known, the widest distance between government and citizens is between the national government and citizens.

In addition to shortening distances, e-government also provides many opportunities for improving the quality of services providing through training civil servants for achieving the readiness of electronic [6]. With e-government, interactions between government and citizens can occur in a fast time, in contrast to the past which requires a long time. That interaction occurs directly without using an intermediary. That will make civil servants get easy, efficient, and effective in their tasks by using electronic instruments [7]. The selection of the right strategy in implementing e-government can improve democratization and services such as citizen get service easily, limitations on the level of public administration, facilities for information seeking and acceptance of services, uncomplicated processes and budget reduction, realization of other objectives and involvement for satisfaction sooner than the needs of citizens [8].

Referring to the many benefits and the number of countries that have implemented them, various international institutions have assessed e-government achievements, particularly in developing democracy. The assessment is manifested in various indexations. Among these are the United Nations with The E-Government Index, and e-Governance Academy Foundation that released The National Cyber Security Index, and the Open Knowledge Foundation that released The Global Open Data Index (GODI), and even some countries assessing the implementation of e-government at every level of government, such as for example Indonesia with Pemeringkatan E-Government Indonesia (PeGI).

Each of these indexations has a different focus on aspects of e-government, among which are aspects of democratization and development, although there is a focus on security performance. For example, the E-government index that measures the level of development and participation. This paper will explain the focus of each index and how it is measured, as well as the utilization of the index. 


\section{Research Methods}

This paper based on literature research. Information and explanation in this paper are obtained through reports that have been published by following institutions in their websites or reports, as well as literature that is relevant to the indexation.

1) UNDESA, E-Government Survey 2018: Gearing E-Government to Support Transformation Towards Sustainable And Resilient Societies. New York: United Nations. https://publicadministration.un.org/egovkb/Portals/egovkb/Documents/un/2018Survey/E-Government\%20Survey\%202018_FINAL_PRINT.pdf

2) Open Knowledge Foundation, The Global Open Data Index (GODI), https://index.okfn.org/

3) e-Governance Academy Foundation, The National Cyber Security Index (NCSI), https://ncsi.ega.ee/

4) Ministry of Communication and Informatics, Pemeringkatan E-Government Indonesia (PeGI), https://pegi.layanan.go.id/

For getting a good understanding, this paper consists of three sessions. First, presenting backgrounds, purposes, and methods. Second, describing the indices, including their scopes and their methodologies. Third, in the last session, I will conclude.

\section{Results and Discussion}

\subsection{Institutions and Their Indices: International and National}

This paper focus on four indices: The E-Government Index from the United Nations, The National Cyber Security Index from e-Governance Academy Foundation, and The Global Open Data Index (GODI) from the Open Knowledge Foundation, and Pemeringkatan EGovernment Indonesia (PeGI) from Ministry of Communication and Informatics. Description about their scope and methodology will be presented one by one.

\subsubsection{E-Government Index}

The E-Government Index [9] was organized by the United Nations Department of Economic and Social Affairs (UNDESA). The index provided data on the application of egovernment. Comparing to other indices, The E-government index was the only global report that assesses the e-government development status of all United Nations Member States. In general, The E-Government Index looked at the effectiveness of the provision of public services that utilize information technology and identifies patterns in the development and performance of e-government. The implementation of the indexation program was expected to be a tool for countries which want to learn from one to others, as well as provide an overview of the strengths and challenges in the e-government so that it can be used as a reference for shaping policies and strategies.

The E-Government Index program was primarily aimed at policymakers, government offices, academics, civil societies, the private sectors, practitioners and other experts in e- 
government and public administration. Data that form the basis of the e-government index were collected through surveys. The survey included the development of e-government based on all aspects in e-government that combines three main dimensions that people can get the benefits from information and services: the sufficiency of telecommunications infrastructure, the quality of human resources to operate and promote the technology, and the availability of information and services. In providing an assessment, the E-government Index released the EGovernment Development Index (EGDI). It was produced from three components; the Telecommunications Infrastructure Index (TII), the Online Service Index (OSI) and the Human Capital Index (HCI).

Each of these components had a different data source. The data source for the Telecommunications Infrastructure Index (TII) was from the International Telecommunications Union (ITU). It was combined from five indicators: amount of fixed broadband subscriptions (per 100 inhabitants), estimation of internet users (per 100 inhabitants), amount of mobile subscribers (per 100 inhabitants), amount of wireless broadband subscriptions (per 100 inhabitants), and amount of fixed telephone lines (per 100 inhabitants). The data source for the Human Capital Index (HCI) was from the United Nations Educational, Scientific and Cultural Organization (UNESCO). It was combined from four components: combination of primary, secondary and tertiary ratio of gross enrolment, average schooling years, expected schooling years, and rate of adult literacy. The data source for the Online the Service Index (OSI) is from UNDESA through a survey that involved experts and online United Nations Volunteers (UNVs). They came from over 60 countries who speak in 66 languages for understanding each country's portal, including the national portal, eparticipation portal, e-services portal and ministerial portals.

The combination from each component was then scored between 0 to 1 . The survey used a questionnaire that assesses aspects of online service delivery. The aspects are government approaches, open government data, multi-channel service delivery, e-participation, mobile services, usage uptake, and innovative partnerships. Besides the E-Government Index, the EParticipation Index (EPI) is also provided. It focused on how e-government is utilized. Some aspects of the index are the level of online service used for providing information (einformation sharing), communication between the government and stakeholders (econsultation) and citizen involvement in the decision-making process (e-decision-making).

\subsubsection{The Global Open Data Index (GODI)}

The Global Open Data Index (GODI) [10] was an independent assessment of citizens' perspectives on the level of government disclosure. This index provided information to stakeholders to find out the government's commitment to publishing information. Through The GODI, stakeholders provided direct feedback. The basic question in the GODI was about how governments openly publish data. The basic question was stated in the following questions. Which governments were ready to publish open data? Which governments did still need to improve the disclosure of open data? What was the most open set of data? What was the least open set of data? Which aspects of open data are the most-easy or the most difficult to implement?

Pacifically, the GODI focused on data about budget, election result, spending, procurement, ownership of land, register of company, national maps, statistics in national level, administrative boundaries, draft legislation, location, national regulations, quality of air and quality of water. In the budget, they looked at data that present expenditure planning of government for next year, and not the current. In spending, they looked at government 
spending in recent or past time, including transactions. In procurement, they looked at all projects and awards. In a result of the election, they looked at data that present the result of the elections in the past and newest, including the outcomes and the process. In the company register, they looked at lists of companies that are registered, no need to include detailed financial data. In the land ownership, they looked at land maps, that present the parcel layer that displays boundaries.

In national maps, they looked at a whole country map, that present water stretches, routes of national traffic, and height markings. In administrative boundaries, they looked at information on units or areas that present the purpose of local government administration. In Locations, they looked at entire country data that present postcodes/zipcodes, latitude, and longitude. In National statistics, they looked at the entire country data that present indicators of economic and demographic statistics, including Gross Domestic Product (GDP), population, and jobless citizen. In Draft legislation, they looked at data that present the draft legislation which is processed in legislative institutions, and their supporting. In national law, they looked at data that present all laws at the national level and statutes. In air quality, they looked at data that present the pollutants' mean concentration for each day, particularly the pollutants that able to make health problems. In water quality, they looked at data that present the designated sources of drinking water quality. If no information were available on the designated sources of drinking water, this referred to environmental sources of water.

Those aspects were examined by questions regarding the Open Definition and the Open Data Charter. By the questions, they made scoring for the aspects. The score and the questions are: 15 points for whether user can access the information by online without registering and permission, 15 points for whether the information is free without payment, 15 points for whether the information can be downloaded in same time, 20 points for whether the information is published in licensed or public domain?, 15 points for whether the information is up-to-date, and 20 points for whether the information is created in common formats so will be easy to open.

\subsubsection{The National Cyber Security Index}

The National Cyber Security Index (NCSI) [11] was a index that evaluated countries' ability to anticipate and defense from cyber-attacks or threats and manage incidents that come from cyber activities. This index provided data that present factual evidence and can be used in capacity building for cybersecurity. The NCSI used indicators based on the national cybersecurity framework. Referring to the framework, the most dangerous threats are a denial of e-services, data integrity breach, and data confidentiality breach. Denial of e-services is a condition when the host or user cannot access the website. Data integrity breach is a condition when the host cannot modify the website. Data confidentiality breach is a condition when the secrecy is exposed

To produce the index, they followed five steps. First, identifying cyber threats at the national government level. Second, measuring the capacity of security. Third, choosing important aspects that can be measured. Fourth, developing indicators of cybersecurity. Finally, grouping indicators of security. This index focused on some aspects of cybersecurity that be adopted by the national government. They are legislation in force, established units, cooperation formats, and outcomes. Legislation referred to legal acts, orders, laws or regulations, and so on. Established units referred to existing departments, organizations, and so on. Format of cooperation referred to working groups, committees, and so on. Results referred to policies, websites, technologies, exercises, programs, and so on. 
The aspects were broken down into 12 capacities, including cyber security policy development, analyzing cyber informing and threats, professional and education development, contributing to international cyber security, digital services protection, essential services protection, trust and E-identification services, personal data protection, response to cyber incidents, cyber crisis management, cyber-crime fighting, and military operations on cyber. Then the capacities had 46 indicators totally. Each indicator had value that presented the significance of the indicator relative to this index. The expert group gave the values by considering the following points. 1 point for a regulation that focused on specific areas. 2-3 points for specialized units. 2 points for formats of official cooperation. 1-3 points for products/results. Besides the NCSI Score, they also released the Digital Development Level (DDL). This Digital Development Level (DDL) was measured by the Networked Readiness Index (NRI) and the ICT Development Index (IDI). Basically, This DDL was the average percentage that the country received from the maximum value of the two indices.

\subsubsection{E-government ranking of Indonesia (PeGI)}

E-government ranking of Indonesia (PeGI) [12] was an assessment conducted by the eGovernment Directorate- Ministry of Communication and Informatics. This ranking measured the achievements of e-government in Indonesian local government. The purpose of this assessment was to obtain a map of the conditions for the utilization of ICTs in the national government environment, provided a reference for the development and utilization of ICTs in the government environment, and provided encouragement for improving the utilization of ICTs in the government environment through a balanced, integrated and objective evaluation.

This assessment evaluated five aspects: policy, institutional, infrastructures, applications, and planning. Each aspect had some indicators. The indicators in policy aspects consist of evaluating official documents that have legality. The documents included among others item and objective/direction determination, work programs, procedures or arrangements for the egovernment implementation and development in an institutional environment. The document form could be in the form of guidelines, regulations, decrees or other official document forms. Allocation of funding sufficient to properly develop and implement ICTs is one of the aspects that are evaluated in policy aspects

The indicators in the institutional aspect consist of the existence of a complete structural organization so that it can carry out the functions of ICT development, governance, operation, ICT services provision and other functions properly. Other indicators are documents that provide a clear formulation of duties and functions, the completeness of work units and their apparatus to support the utilization and development of adequate ICTs in terms of numbers, competencies, career paths, and employment status. The last indicator is sufficient authority so that the institution can carry out its duties and functions properly including the control and supervision functions of the development and implementation of ICT in participating agencies.

The indicators in infrastructure aspects consist of data center (computer software and hardware), communication networks (Internet access, WAN, LAN), hardware and software for users (desktops, notebooks, etc.), channels of service delivery (SMS, telephone and others), and facilities that supported them, it was like special rooms, air conditioning, generators, UPS and other security facilities. The indicators in application aspects consist of availability and level of utilization of application software that supported services on e-government directly ("front office") or indirectly ("back office"), availability and various application levels that need to carry out functions of e-government in line with the tasks and the agency functions. 
They evaluated the applications in nine categories. Service applications, including applications for taxation and user fees, population, business and investment, registration and licensing, public complaints, governance publications and public information, and so on. Administration and management applications, including applications of e-mail, systems of edocument, systems of decision support, collaboration and coordination, management of government reporting, and so on. Legislation applications, including the council administration system applications, the system of regional electoral, regulations and legislation, the legal catalog, and others. Development applications, including applications to support development data, regional development planning, procurement of goods and services, project management and monitoring, evaluation and information on development results, and others. Financial applications, including budget applications, cash and treasury, accounting in regional levels, and others. Staffing applications, including applications for hiring employees, payroll, attendance, education and training, performance appraisal, and others.

Governance applications, including management of regional goods, management of regional revenues and management of regional companies. Territorial applications, including spatial planning and the environment, regional potential, forestry, agriculture, animal husbandry and plantations, fisheries and marine affairs, mining and energy, tourism and small and medium industries. Community applications, including health, education, employment, industry and trade applications, and social safety nets. Application of facilities and infrastructure, including among others the application of transportation, roads and bridges, terminals and ports, and public facilities. In evaluating applications, they considered compliance with the agency's and stakeholder's priority needs, suitability with factual conditions (infrastructure availability, levels of competency of human resource, etc.), efficiency and effectiveness of agencies in quality services both external and internal, ability to adapt to changes over time, and minimal autonomy.

The indicators in planning aspects consist of the existence of a ICT's development and utilization planning process that is carried out in a tangible manner (procedures, standardized and regular work mechanisms), the need for a complete assessment of the needs and strategies for implementing ICT, the decision making implementation and the development realization which referred to the plan of development.

The assessment method is obtained through seven stages. First, provide an explanation of the process to participants. Second, participants filled out the questionnaire. Third, the assessor checks the questionnaire. Fourth, the assessor clarifies the answer (if needed). Fifth, assessors give scores for these indicators. Sixth, assessors normalize. Seventh, the assessor conducts a results hearing. The ranking is as follows: Very good if the agency gets a score of $3.60-4.00$. Good, if the agency gets a score of $2.60-3.59$. Less, if the agency gets a score of $1.60-2.59$. Very less, if the agency gets a score of $1.00-1.59$.

\section{Conclusion}

The various indices can be grouped into three indices, namely the managerial indices, the human resources indices, and the democratic indices. The managerial indices refer to assessing how governments develop and maintain e-government. The human resources indices refer to assessing human capability for operating and accepting the e-government. The democratic indices refer to assessing how the e-government becomes a channel of interaction 
between government and citizens. The indices that can be categorized as managerial indices are:

- Telecommunication Infrastructure Index (TII), which talked about estimated users of internet, total of main fixed telephone lines, total of broadband subscriptions, total of wireless broadband subscriptions, and total of mobile subscribers.

- The Online the Service Index (OSI), which talked about the national portal, e-services portal, and e-participation portal, as well as the websites of the related ministries.

- The National Cyber Security Index (NCSI), which talked about denial of e-services, data integrity breach, and data confidentiality breach.

- The Digital Development Level (DDL), which talked about the Networked Readiness Index (NRI) and the ICT Development Index (IDI).

- E-government ranking of Indonesia (PeGI), which talked about policy, institutional, infrastructures, applications, and planning.

The indices that can be categorized as human resources indices are:

- The Human Capital Index (HCI), which talked about the combined tertiary, secondary and primary gross enrolment ratio, rate of adult literacy, schooling average years, and schooling expected years.

The indices that can be categorized as democratic indices are:

- The E-Participation Index (EPI), which talked about providing information (einformation sharing), communication between the government and stakeholders (econsultation) and citizen involvement in the decision-making process (e-decisionmaking).

- The Global Open Data Index (GODI), which talked about how to publish budget, procurement, spending, result of election, ownership of land, company register, national maps, location, administrative boundaries, statistics in national level, national regulations, draft legislation, quality of water and quality of air.

Based on the categorization, it is known that more indices talked about how to develop egovernment, which had four indexes. The rarest assessment is about the level of human resources, actors in the government and community. While the assessment of the benefits of egovernment for democracy is only presented by two indices.

\section{References}

[1] G. Spirakis, C. Spiraki, and K. Nikolopoulos, "The impact of electronic government on democracy: e-democracy through e-participation," Electron. Gov. an Int. J., vol. 7, no. 1, pp. 7588, 2010.

[2] A. De Kleine, S. Streifel, E. Ju Kim, M. Riordan, and C. Savescu, "The e-government handbook for developing countries: a project of InfoDev and the Center for Democracy and Technology."

[3] European Commission, Transforming Government. Brussels: European Commission, 2005.

[4] I. C. for P. Studies, E-Government: Achievements in the Name of Democracy. kiev: International Centre for Policy Studies, 2003.

[5] U. Nations, World Public Sector Report 2003: E-Government at the Crossroads. New York, 2003.

[6] A. K. Aggarwal, “A training model for e-readiness in e-governance," Electron. Gov. an Int. J., vol. 6, no. 2, pp. 111-128, 2009.

[7] F. Matthias, M. Gianluca, and R. Pierre, "Governance with and of ICTs: the need for new institutional designs in a changing world," e-Gov Mag., vol. 2, 2006.

[8] A. Ghapanchi, A. Albadvi, and B. Zarei, "A framework for e-government planning and implementation," Electron. Gov. An Int. J., vol. 5, no. 1, pp. 71-90, 2008.

[9] UNDESA, E-Government Survey 2018: Gearing E-Government To Support Transformation 
Towards Sustainable And Resilient Societies. New York: United Nations.

[10] "Open Knowledge Foundation, The Global Open Data Index (GODI)." [Online]. Available: https://index.okfn.org/.

[11] “e-Governance Academy Foundation, The National Cyber Security Index (NCSI)." [Online]. Available: https://ncsi.ega.ee/.

[12] Ministry of Communication and Informatics, "Pemeringkatan E-Government Indonesia (PeGI)." [Online]. Available: https://pegi.layanan.go.id/. 